\title{
Impact of Renin-Angiotensin System Inhibitors On The Survival of Patients With Rectal Cancer
}

\section{Marcin Zeman ( $\nabla$ mzeman@wp.pl)}

Maria Skłodowska-Curie National Research Institute of Oncology, Gliwice Branch, Wybrzeże Armii Krajowej 15, 44-102 Gliwice, Poland

\section{Władysław Skałba}

Maria Skłodowska-Curie National Research Institute of Oncology, Gliwice Branch, Wybrzeże Armii Krajowej 15, 44-102 Gliwice, Poland

\section{Agata M. Wilk}

Maria Skłodowska-Curie National Research Institute of Oncology, Gliwice Branch, Wybrzeże Armii Krajowej 15, 44-102 Gliwice, Poland

\section{Alexander J. Cortez}

Maria Skłodowska-Curie National Research Institute of Oncology, Gliwice Branch, Wybrzeże Armii Krajowej 15, 44-102 Gliwice, Poland

\section{Adam Maciejewski}

Maria Skłodowska-Curie National Research Institute of Oncology, Gliwice Branch, Wybrzeże Armii Krajowej 15, 44-102 Gliwice, Poland

\section{Agnieszka Czarniecka}

Maria Skłodowska-Curie National Research Institute of Oncology, Gliwice Branch, Wybrzeże Armii Krajowej 15, 44-102 Gliwice, Poland

\section{Research Article}

Keywords: rectal cancer, renin-angiotensin system inhibitors, angiotensin-converting enzyme inhibitors, ACEl, angiotensin receptor blockers, ARB, arterial hypertension

Posted Date: October 28th, 2021

DOl: https://doi.org/10.21203/rs.3.rs-984417/v1

License: (c) (i) This work is licensed under a Creative Commons Attribution 4.0 International License. Read Full License 


\title{
Impact of renin-angiotensin system inhibitors on the survival of patients with rectal cancer
}

\author{
Marcin Zeman ${ }^{1 *}$, Władysław Skałba ${ }^{1}$, Agata M. Wilk ${ }^{2,3}$, Alexander J. Cortez ${ }^{2}$, Adam Maciejewski ${ }^{1}$ and \\ Agnieszka Czarniecka ${ }^{1}$
}

\footnotetext{
${ }^{*}$ Correspondence: mzeman@wp.pl

${ }^{1}$ The Oncologic and

Reconstructive Surgery Clinic,

Maria Sklodowska-Curie National

Research Institute of Oncology,

Wybrzeze Armii Krajowej 15,

44-102 Gliwice, Poland

Full list of author information is

available at the end of the article
}

\begin{abstract}
Background: Renin-angiotensin system inhibitors (RASIs) are widely used in the treatment of hypertension. However, their impact on the outcome of the combined treatment of rectal cancer is poorly understood. The aim of this study was to assess the effect of RASIs on the survival of rectal cancer patients with associated hypertension after neoadjuvant treatment and radical resection.
\end{abstract}

Methods: Between 2008 and 2016, 242 radical (R0) rectal resections for cancer were performed after neoadjuvant treatment in patients with associated hypertension. At the time of treatment, 158 patients were on RASls, including 35 angiotensin-receptor antagonists (ARB) users and 123 angiotensin-converting enzyme inhibitors (ACEI) users. Eighty-four patients were on drugs other than RASIs (non-RASI users). The survival analysis was performed using the Kaplan-Meier estimator with the log-rank test and the Cox proportional hazards model.

Results: The log-rank test showed a significantly worse overall survival (OS) in the group of ACEI users compared to ARB users $(p=0.009)$ and non-RASI users $(p=0.013)$. As regards disease-free survival (DFS), worse survival was found in the ACEl group compared to ARB users and it was close to the statistical significance level $(p=0.064)$. The Multivariate Cox analysis showed a significant beneficial effect of ARBs on OS ( $H R: 0.326,95 \% C I: 0.147-0.724, p=0.006$ ) and ARBs on DFS ( $H R: 0.339,95 \% C I: 0.135-0.850, p=0.021)$ compared to ACEls. Other factors affecting OS included age

( $H R: 1.044,95 \% C I: 1.016-1.073, p=0.100)$, regional lymph node metastasis $(\mathrm{ypN}+)(H R: 2.157,95 \% C I: 1.395-3.334, p=0.001)$ and perineural invasion (PNI) $(H R: 3.864,95 \% C I: 1.799-8.301, p=0.001)$. Additional factors affecting DFS included ypN+ $(H R: 2.310,95 \% C I: 1.374-3.883, p=0.002)$ and PNI ( $H R: 4.351,95 \% C I: 1.584-11.954, p=0.004)$.

Conclusions: The use of ARBs instead of ACEls may improve the outcome of the combined therapy for rectal cancer patients with associated hypertension.

Keywords: rectal cancer; renin-angiotensin system inhibitors; angiotensin-converting enzyme inhibitors; ACEl; angiotensin receptor blockers; ARB; arterial hypertension

\section{Background}

Hypertension is a common comorbidity in patients with colorectal cancer [1]. In addition, it was shown that patients with hypertension could have an increased risk of developing colorectal cancer [2]. The circulatory renin-angiotensin system (RAS) is a regulator of sodium and water homeostasis. It is one of the phylogenet- 
ically oldest endocrine systems of vertebrates [3]. In kidney cells, prorenin is converted to renin, which is secreted into the circulation. Renin causes the conversion of angiotensinogen produced in the liver to angiotensin I, which is then converted to angiotensin II (AngII) by angiotensin-converting enzyme (ACE). AngII can directly act on vessel walls causing their contraction, and it stimulates the adrenal cortex to secrete aldosterone. Furthermore, the presence of tissue RAS (tRAS) was demonstrated. It plays an important role in the pathogenesis of cardiovascular, inflammatory, autoimmune, and neoplastic diseases [4]. RAS inhibitors (RASIs), which include angiotensin-converting enzyme inhibitors (ACEIs) and angiotensin receptor antagonists (ARBs), are widely used in the treatment of arterial hypertension. Although both groups of drugs block the RAS, their mechanism of action is different. ACEIs inhibit AngII production, whereas ARBs block the action of AngII by antagonizing the angiotensin II type 1 receptor (AT1R). In addition, ACEIs influence the kallikrein-kinin system (KKS) by inhibiting the catabolism of kinins to inactive metabolites [5]. Population-based studies showed that RASIs could reduce the prevalence of colorectal cancer. However, their impact on the long-term outcomes of colorectal cancer has been poorly understood [6]. Possible mechanisms for the effects of these drugs on cancer include their inhibitory effect on angiogenesis and modulation of the immune system by affecting tRAS components in the tumor setting [7]. In many studies, the influence of both groups of these drugs on the results of cancer treatment is analyzed jointly. However, it seems that due to the different mechanisms of action, these groups should be assessed separately.

\section{Methods}

Aim of the study

To assess the effect of RASIs on overall survival (OS) and disease-free survival (DFS) of rectal cancer patients without synchronous distant metastases with associated hypertension after neoadjuvant treatment and radical resection.

\section{Patients}

Between 2008 and 2016, 242 radical (R0) rectal resections for cancer were performed at our center after neoadjuvant treatment in patients without distant metastases with associated hypertension. The enrolment procedure is shown in the diagram [see Additional file 1]. To avoid including patients with synchronous microdissemination in the analysis, metastases clinically detected within 3 months postoperatively were considered synchronous metastases. The severity of the associated diseases was assessed using the Charlson comorbidity index (CCI) [8].

\section{Procedures}

All patients received neoadjuvant treatment, i.e., radiotherapy (RT) at a total dose of 25-42 Gy or chemoradiotherapy (CRT) at a dose of 42-54 Gy combined with one or two cycles of 5-fluorouracil-based chemotherapy. All procedures were performed by colorectal surgeons or under their direct supervision. Laparotomy with total mesorectal excision was performed. Postoperative complications were assessed using the Clavien-Dindo scale. Tumor regression grade (TRG) was based on the assessment of the degree of fibrosis compared to the residual tumor tissue and ranged 
from 0 to 3, i.e., 0 (complete response), 1 ( $<10 \%$ residual tumor), $2(10-50 \%)$ and $3(>50 \%)$. During the analyzed period, adjuvant chemotherapy was based on 5fluorouracil. The characteristics of the study group are shown in Table 1. After the end of treatment, all patients were under continuous follow-up in our center.

\section{Table 1}

\section{Variables}

The following potential risk factors were considered in the survival analysis: age, sex, body mass index (BMI), drugs used for comorbidities at the time of enrolment for surgery, CCI, tumor location in the rectum, neoadjuvant treatment (RT or CRT), cancer stage before treatment, type of surgery, occurrence of postoperative complications, tumor invasion depth (ypT), nodal staging (ypN), lymph vessel invasion (LVI), perineural invasion (PNI), TRG, lymph node yield (LNY), and adjuvant chemotherapy.

\section{Statistical methods}

Categorical variables were summarized as frequencies and percentages, and continuous variables were shown as median values with interquartile ranges $(25 \%$ to $75 \%$, IQR25 - 75) unless otherwise stated. Pairwise comparisons between patient subgroups were performed by the Fisher exact test for categorical variables, and the odds ratio (OR) was calculated. For continuous variables, comparisons between two groups were determined using the Wilcoxon rank sum test. OS was defined as the time from surgery until death, or the last known date alive. DFS was calculated from the time of surgery to the date of the last follow-up without the development of local or distant recurrence. The survival analysis was performed using the survival package (v. 3.2-7) [9] and the glmnet package (v. 4.1-1) [10]. Visualizations were prepared with the survminer package (v. 0.4.8) [11]. Survival curves were plotted with the Kaplan-Meier method and compared using the log-rank test (the Mantel-Haenszel test). Univariate and multivariate analyses with the survival endpoint were investigated by the Cox proportional-hazards model, verifying the proportional hazard assumption with Schoenfeld residuals. Significant risk factors were selected by applying several methods, i.e., preselection with the univariate Cox analysis (variables with p-value $<0.200$ were included in the multivariate analysis), recursive elimination based on the Akaike information criterion (AIC), and the least absolute shrinkage and selection operator (LASSO) [12]. The complete report from Cox proportional-hazards model regression analyses is given in Additional file 2. All analyses were performed using the $\mathrm{R}$ environment for statistical computing version 4.0.2 "Taking off Again" released on June 22, 2020 (R Foundation for Statistical Computing, Vienna, Austria, http://www.r-project.org). A two-sided p-value $<0.05$ was considered statistically significant and p-value $<0.10$ was considered close to the statistical significance level.

\section{Results}

At the time of treatment, 158 patients were on RASIs, including 35 ARB users and 123 ACEI users. Eighty-four patients were on drugs other than RASIs (non-RASI 
users). No significant differences between ARB and ACEI users were found in the frequency of use of other drug groups. Non-RASI users significantly more frequently used beta blockers compared to RASI users $(p=0.001, O R=2.619)$. The drugs used in each group are shown in Table 2. The use of RASIs is shown in Table 3. We found a higher prevalence of complications > grade II (Clavien-Dindo Classification $)(\mathrm{p}=0.015, \mathrm{OR}=2.421)$ and better response (TRG $0-1)$ to neoadjuvant treatment $(p=0.024, O R=1.923)$ in the group of non-RASI users compared to RASI users.

\section{Table 2}

\section{Table 3}

We found a significantly worse OS $(p=0.009)$ in the ACEI-treated group (the log-rank test) compared to ARB-treated patients and non-RASI users $(\mathrm{p}=0.013)$ (Fig.1). However, no significant difference in OS $(\mathrm{p}=0.293)$ was found when ARB users were compared to non-RASI users $(p=0.293)$ [see Additional file 3A].

\section{FIGURE 1}

DFS, which was close to the statistical significance level, was better in the group of ARB users compared to ACEI users $(p=0.064)$ (Fig.2). No difference was found in DFS between ARB users and non-RASI users $(p=0.201)$. Similarly, no difference was reported for DFS when ACEI users were compared to non-RASI users $(p=0.429)$ [see Additional file 3B].

\section{FIGURE 2}

Univariate and multivariate Cox regression models are shown in Table 4. In the multivariate analysis of OS, adverse risk factors included age ( $H R: 1.044,95 \% C I$ : $1.016-1.073, p=0.002), y p N+(H R: 2.157,95 \% C I: 1.395-3.334, p=0.001)$ and PNI $(H R: 3.864,95 \% C I: 1.799-8.301, p=0.001)$. Compared to ACEI users, a significant beneficial effect was found in the case of non-RASI users ( $H R$ : $0.536,95 \% C I: 0.333-0.864, p=0.010)$ and ARB users $(H R: 0.326,95 \% C I$ : $0.147-0.724, p=0.006$ ) (Fig 3A). For DFS, unfavorable factors included ypN+ $(H R: 2.310,95 \% C I: 1.374-3.883, p=0.002)$ and PNI $(H R: 4.351,95 \% C I:$ $1.584-11.954, p=0.004)$. A significant beneficial effect was demonstrated in ARB users ( $H R: 0.339,95 \% C I: 0.135-0.850, p=0.021)$ (Fig 3B). The other analyzed factors did not have a significant influence on survival.

\section{FIGURE 3}

\section{Discussion}

Recently, the role of tRAS has been discussed in the pathogenesis and progression of some cancers. The mechanisms of the influence of tRAS on cancer progression 
may be diverse and can be associated with the effects on proliferation, migration, angiogenesis and immunosuppression [13]. The components of tRAS are present in cells of many cancers, including colorectal cancer and its microenvironment, such as tumor-associated macrophages, regulatory T-cells, or fibroblasts. Through the mechanism of AT1R activation, these cells induce immunosuppression in the tumor microenvironment and affect tumor progression and increase metastatic potential $[13,14]$. Studies using animal models showed that this effect could be reduced by ARBs, which selectively block AT1R [14]. AT1R activation increases the expression of vascular endothelial growth factor (VEGF), which is the main factor responsible for angiogenesis [15]. It was also shown that high expression of the AGTR1 gene encoding the AT1R protein correlated with poorer long-term colorectal cancer outcomes [16]. In addition, through its direct vasoconstrictive effect, AngII, which is the main component of RAS, reduces perfusion in the tumor and its microenvironment leading to hypoxia and acidosis. By enhancing the expression of proinflammatory cytokines, these factors result in cancer-promoting inflammation [13]. To balance the pathway activated by AT1R, RAS also has the so-called "protective arm", including the angiotensin II type 2 receptor (AT2R), ACE2, Angiotensin (1-7), and the Mas receptor (MasR). Its activation produces the effect opposite to the activation of AT1R, including vasodilatory, anti-inflammatory and antiproliferative effects, which are achieved by reducing cytokine levels or inhibiting VEGF expression $[15,17,18]$. When considering the potential influence of RAS on the pathogenesis and the course of cancer, its interactions with KKS should also be considered. Kinins show pro-tumorigenic properties due to their ability to stimulate angiogenesis, cell proliferation and migration [19]. Kallikrein is the main enzyme causing kinin formation, while ACE is the main enzyme cleaving bradykinin (BK) into an inactive form [BK(1-7)]. Thus, the concentration of kinins in tissues depends on the local balance between these two enzymes [20]. Blocking ACE results in an increase in the concentration of BK and desArg9 BK, which is formed from BK under the influence of carboxypeptidases and is the most potent activator of the BK type 1 receptor (B1R). The expression of this receptor increases significantly under inflammatory conditions, whereas it is virtually undetectable under physiological conditions. Degradation of desArg9 BK into inactive metabolites is mediated by ACE2 [21]. The impact of RASIs on this complex mechanism of mutual relationships is poorly understood as regards colorectal cancer outcomes. A recent meta-analysis indicated a beneficial effect of RASIs on the survival of patients with gastrointestinal cancers. However, there are not many papers that assessed the impact of these drugs on colorectal cancer outcomes. In addition, most authors of the papers included in the meta-analysis analyzed the effect of both drug groups jointly (ACEIs/ARBs) [22]. The only meta-analysis which included only patients with colorectal cancer showed that RASIs could be associated with a reduced risk of colorectal cancer. However, no conclusions could be drawn in terms of the effect of these drugs on treatment outcomes [6]. Four studies on colorectal cancer patients, also including stage IV cancers, did not demonstrate the effect of ACEIs/ARBs on patient survival when the analyses without division into subgroups were performed [16, 23, 24, 25]. However, Ozawa et al. demonstrated their beneficial effect on recurrence-free survival in left-sided colorectal cancer and stage I subgroups [16]. In turn, Engineer et al. 
showed significantly better survival when RASIs were combined with a beta-blocker [23]. In a nested case-control study based on the national registry data, Cardwell et al. demonstrated a beneficial effect of ACEIs on cancer-specific mortality in colorectal cancer patients compared to non-users. However, no protective effect of ACEIs was reported after excluding the patients who had started using ACEIs in the year prior to death or when the analysis was restricted to users of any antihypertensive medication in the year prior to cancer diagnosis [26]. In contrast, Heinzerling et al. demonstrated that not using ACEIs was an unfavorable predictor of distant metastases in patients with stage II colorectal cancer [27]. The results of the study of the effect of ARBs on survival are also inconsistent. In the analysis of colorectal cancer patients (stages I-IV), Cui et al. showed significantly better OS and DFS in the users of ARBs or beta-blockers compared to those who did not use these drugs [28]. Osumi et al. showed that in metastatic colorectal cancer, patients treated with bevacizumab who also used ARBs had significantly better OS and progression-free survival compared to ARB non-users [29]. However, Cardwell et al. found no effect of ARBs on colorectal cancer-specific mortality in the population-based study [26]. To the best of our knowledge, there have been no reports assessing the effect of RASI groups (i.e., ACEI vs. ARB) on long-term survival in rectal cancer patients after combined treatment. Only one paper assessed the effect of RASIs on the survival of rectal cancer patients only. However, both drug groups were evaluated jointly. Morris et al. showed that the use of ACEI/ARB significantly increased the rate of tumor pathological complete response $(\mathrm{pCR})$ to preoperative RT. Those authors showed no effect of these drugs on OS, local recurrence-free survival, or metastasis-free survival; neither did they demonstrate the effect of pCR on survival [30]. In contrast, Rombouts et al. did not confirm the effect of ACEI/ARB on pCR. They showed a beneficial effect of beta-blockers in the multivariate analysis. However, they did not conduct the survival analysis [31]. In our study, we observed a higher percentage of positive responses to RT (TRG 0-1) in non-RASI users. We showed significantly worse OS in ACEI users compared to ARB and non-RASI users and worse DFS, which was close to the statistical significance level, in ACEI users compared to ARB users. In the multivariate Cox analysis, in addition to the influence of known risk factors such as age, ypN or PNI, the use of ACEIs was an unfavorable prognostic factor for OS, whereas ARBs showed a favorable effect on DFS. These results showed that tRAS could have a significant impact on the course of the disease, and its inhibition by different RASI groups may produce different effects. The potential mechanisms of this phenomenon are poorly understood, and hence further studies are warranted. They are most likely due to the different mechanisms of action of both RASI groups. ARBs block the RAS more effectively than ACEIs because approximately $40 \%$ of AngII is formed in non-ACE pathways [32]. In addition, while ARBs selectively block the ACE/AngII/AT1R proinflammatory pathway, they can simultaneously activate the AT2R/ACE2/Ang1-7/MasR antiinflammatory pathway $[4,33]$. Such diverse effects are not demonstrated by ACEIs, which may additionally exert adverse effects by blocking kinin degradation. Our results indicate that further studies are necessary to confirm whether the use of ARBs (instead of ACEIs) may lead to improved long-term oncological outcomes in rectal cancer patients. It is crucial since both groups of drugs have comparable efficacy 
in the treatment of cardiovascular disease. However, a lower risk of side effects is reported in the case of ARBs [5]. It seems that it is warranted to analyze ARBs and ACEIs separately in terms of their impact on long-term oncological outcomes because their different mechanisms of action may differently affect the course of the cancer disease. The study has limitations typical of single-center and retrospective analyses. Data on comorbidities and drug use were collected from the records of consultant internal physicians and anesthesiologists before surgery. It was not possible to assess the duration of drug use. The smaller size of the group of ARB users is due to the fact that ARBs are less commonly used compared to ACEIs. This is most likely related to significantly higher costs of treatment with ARBs during the analyzed period due to the later introduction of generics compared to ACEIs.

\title{
Conclusions
}

The use of ARBs, instead of ACEIs, may improve the long-term outcome of the combined treatment of rectal cancer patients with associated hypertension.

\section{Appendix}

\author{
Acknowledgements \\ We also acknowledge the translation assistance provided by Assistant Professor Arkadiusz Badziński, Ph.D., a \\ medical translator and interpreter. \\ Funding \\ This research received no external funding; A.J.C. was co-financed by the European Union through the \\ European Social Fund (grant no. POWR.03.02.00-00-1029). \\ Abbreviations \\ ACE- angiotensin-converting enzyme, ACEI- angiotensin-converting enzyme inhibitors, Angll- angiotensin II, \\ Ang(1-7)- angiotensin (1-7), ARB- angiotensin receptor blockers, AT1R- Angiotensin II type I receptor, AT2R- \\ Angiotensin II type II receptor, BMI- body mass index, BK- bradykinin, B1R- bradykinin type 1 receptor, CCI- \\ Charlson Comorbidity Index, Cl- confidence interval, CRT- chemoradiotherapy, DFS- disease-free survival, HR- \\ hazard ratio, IQR- interquartile range, KKS- kallikrein-kinin system, LNY- lymph node yield, LVI- \\ lymphovascular invasion, MasR- Mas receptor, OR- odds ratio, OS- overall survival, pCR- pathological \\ complete response, PNI- perineural invasion, RAS- renin-angiotensin system, RASI- renin-angiotensin system \\ inhibitors, RT- radiotherapy, tRAS- tissue renin-angiotensin system, TRG- tumor regression grade
}

Availability of data and materials

The dataset supporting the conclusions of this article is included within the article [see Additional file 4]

Ethics approval and consent to participate

This retrospective study was conducted in accordance with the ethical standards of the institutional research committee and with the 1964 Helsinki Declaration and its later amendments. The study was approved by the institutional ethics committee of the National Research Institute of Oncology (KB/430-53/19). Due to the retrospective design of the study, the ethics committee confirmed that informed consent was not necessary from participants.

Competing interests

The authors declare that they have no competing interests.

Consent for publication

Not applicable

Authors' contributions

$M Z$ participated in the study conception and design, MZ and WS participated in the acquisition of the data, AJC, AW and MZ participated in the data analysis and interpretation, MZ drafted the manuscript, AM and AC substantively revised the manuscript. All authors read and approved the final manuscript.

Author details

${ }^{1}$ The Oncologic and Reconstructive Surgery Clinic, Maria Sklodowska-Curie National Research Institute of Oncology, Wybrzeze Armii Krajowej 15, 44-102 Gliwice, Poland. ${ }^{2}$ Department of Biostatistics and Bioinformatics, Maria Skłodowska-Curie National Research Institute of Oncology, Gliwice Branch, 44-102 Gliwice, Wybrzeze Armii Krajowej 15, 44-102 Gliwice, Poland. ${ }^{3}$ Department of Systems Biology and Engineering, Silesian University of Technology, Akademicka 16, 44-100 Gliwice, Poland. 
References

1. Reddy, S., Mouchli, A., Bierle, L., Gerrard, M., Mir, A., Lebel, D.P., Mason, C., Grider, D., M, R.: Assessing presenting symptoms, co-morbidities, and risk factors for mortality in underserved patients with non-hereditary early-onset colorectal cancer. Cureus 13(7), 16117 (2021). doi:10.7759/cureus.16117

2. Xuan, K., Zhao, T., Sun, C., Patel, A.S., Liu, H., Chen, X., Qu, G., Sun, Y.: The association between hypertension and colorectal cancer: a meta-analysis of observational studies. Eur J Cancer Prev 30(1), 84-96 (2021). doi:10.1097/cej.0000000000000578

3. Labandeira-Garcia, J.L., Valenzuela, R., Costa-Besada, M.A., Villar-Cheda, B., Rodriguez-Perez, A.I.: The intracellular renin-angiotensin system: Friend or foe. some light from the dopaminergic neurons. Prog Neurobiol 199, 101919 (2021). doi:10.1016/j.pneurobio.2020.101919

4. Saravi, B., Li, Z., Lang, C.N., Schmid, B., Lang, F.K., Grad, S., Alini, M., Richards, R.G., Schmal, H., Südkamp, N., Lang, G.M.: The tissue renin-angiotensin system and its role in the pathogenesis of major human diseases: Quo vadis? Cells 10(3), 650 (2021). doi:10.3390/cells10030650

5. Turner, J.M., Kodali, R.: Should angiotensin-converting enzyme inhibitors ever be used for the management of hypertension? Curr Cardiol Rep 22(9) (2020). doi:10.1007/s11886-020-01352-8

6. Dai, Y.N., Wang, J.H., Zhu, J.Z., Lin, J.Q., Yu, C.H., Li, Y.M.: Angiotensin-converting enzyme inhibitors/angiotensin receptor blockers therapy and colorectal cancer: a systematic review and meta-analysis. Cancer Cause Control 26(9), 1245-1255 (2015). doi:10.1007/s10552-015-0617-1

7. Okwan-Duodu, D., Landry, J., Shen, X.Z., Diaz, R.: Angiotensin-converting enzyme and the tumor microenvironment: mechanisms beyond angiogenesis. Am J Physiol-Reg I 305(3), 205-215 (2013). doi:10.1152/ajpregu.00544.2012

8. Charlson, M.E., Pompei, P., Ales, K.L., MacKenzie, C.R.: A new method of classifying prognostic comorbidity in longitudinal studies: Development and validation. J Chron Dis 40(5), 373-383 (1987). doi:10.1016/0021-9681(87)90171-8

9. Therneau, T.: A Package for Survival Analysis in R. R package version 3.2-7 (2021). https://CRAN.R-project.org/package=survival

10. Friedman, J., Hastie, T., Tibshirani, R.: Regularization paths for generalized linear models via coordinate descent. J Stat Softw 33(1) (2010). doi:10.18637/jss.v033.i01

11. Kassambara, T.e.a.: survminer: Drawing Survival Curves using 'ggplot2'. R package version 0.4.8 (2021). https://CRAN.R-project.org/package=survminer

12. Tibshirani, R.: The lasso method for variable selection in the cox model. Stat Med 16(4), 385-395 (1997) doi:10.1002/(sici)1097-0258(19970228)16:4<385::aid-sim380>3.0.co;2-3

13. Jiang, H., Tai, Z., Chen, Z., Zhu, Q., Bao, L.: Clinical applicability of renin-angiotensin system inhibitors in cancer treatment. Am J Cancer Res 11, 318-336 (2021)

14. Nakamura, K., Yaguchi, T., Ohmura, G., Kobayashi, A., Kawamura, N., Iwata, T., Kiniwa, Y., Okuyama, R., Kawakami, Y.: Involvement of local renin-angiotensin system in immunosuppression of tumor microenvironment. Cancer Sci 109(1), 54-64 (2018). doi:10.1111/cas.13423

15. Carbajo-Lozoya, J., Lutz, S., Feng, Y., Kroll, J., Hammes, H.P., Wieland, T.: Angiotensin II modulates VEGF-driven angiogenesis by opposing effects of type 1 and type 2 receptor stimulation in the microvascular endothelium. Cell Signal 24(6), 1261-1269 (2012). doi:10.1016/j.cellsig.2012.02.005

16. Ozawa, T., Hashiguchi, Y., Yagi, T., Fukushima, Y., Shimada, R., Hayama, T., Tsuchiya, T., Nozawa, K., linuma, H., Ishihara, S., Matsuda, K.: Angiotensin i-converting enzyme inhibitors/angiotensin II receptor blockers may reduce tumor recurrence in left-sided and early colorectal cancers. Int J Colorectal Dis 34(10), 1731-1739 (2019). doi:10.1007/s00384-019-03379-y

17. Patel, S., Hussain, T.: Dimerization of at 2 and mas receptors in control of blood pressure. Curr Hypertens Rep 20(5), 41 (2018). doi:10.1007/s11906-018-0845-3

18. Simões e Silva, A.C., Silveira, K.D., Ferreira, A.J., Teixeira, M.M.: Ace2, angiotensin-(1-7) and mas receptor axis in inflammation and fibrosis. Br J Pharmacol 169(3), 477-92 (2013). doi:10.1111/bph.12159

19. da Costa, P.L., Sirois, P., Tannock, I.F., Chammas, R.: The role of kinin receptors in cancer and therapeutic opportunities. Cancer Lett 345(1), 27-38 (2014). doi:10.1016/j.canlet.2013.12.009

20. Alhenc-Gelas, F., Bouby, N., Girolami, J.P.: Kallikrein/k1, kinins, and ace/kininase ii in homeostasis and in disease insight from human and experimental genetic studies, therapeutic implication. Front Med (Lausanne) 27(6), 136 (2019). doi:10.3389/fmed.2019.00136

21. Warner, F.J., Smith, A.I., Hooper, N.M., Turner, A.J.: Angiotensin-converting enzyme-2: a molecular and cellular perspective. Cell Mol Life Sci 61(21), 2704-13 (2004). doi:10.1007/s00018-004-4240-7

22. Zhou, Q., Chen, D.S., Xin, L., Zhou, L.Q., Zhang, H.T., Liu, L., Yuan, Y.W., Li, S.H.: The renin-angiotensin system blockers and survival in digestive system malignancies. Medicine 99(7), 19075 (2020). doi:10.1097/md.0000000000019075

23. Engineer, D.R., Burney, B.O., Hayes, T.G., Garcia, J.M.: Exposure to ACEI/ARB and $\beta$-blockers is associated with improved survival and decreased tumor progression and hospitalizations in patients with advanced colon cancer. Transl Oncol 6(5), 539-545 (2013). doi:10.1593/tlo.13346

24. Holmes, S., Griffith, E.J., Musto, G., Minuk, G.Y.: Antihypertensive medications and survival in patients with cancer: A population-based retrospective cohort study. Cancer Epidemiol 37(6), 881-885 (2013). doi:10.1016/j.canep.2013.09.001

25. Mafiana, R.N., Al-Kindi, M.S., Mafiana, N., Al Lawati, A.S., Al Moundhri, M.: Impact of metabolic syndrome diagnosis and its treatment on survival of colorectal cancer patients. J Cancer Epidemiol 2019, 1-9 (2019). doi:10.1155/2019/6527457

26. Cardwell, C.R., Mc Menamin, Ú.C., Hicks, B.M., Hughes, C., Cantwell, M.M., Murray, L.J.: Drugs affecting the renin-angiotensin system and survival from cancer: a population based study of breast, colorectal and prostate cancer patient cohorts. BMC Medicine 12(1) (2014). doi:10.1186/1741-7015-12-28

27. Heinzerling, J.H., Anthony, T., Livingston, E.H., Huerta, S.: Predictors of distant metastasis and mortality 
in patients with stage II colorectal cancer. Am Surg 73(3), 230-238 (2007)

28. Cui, Y., Wen, W., Zheng, T., Li, H., Gao, Y.T., Cai, H., You, M., Gao, J., Yang, G., Zheng, W., Xiang, Y.B., Shu, X.O.: Use of antihypertensive medications and survival rates for breast, colorectal, lung, or stomach cancer. Am J Epidemiol 188(8), 1512-1528 (2019). doi:10.1093/aje/kwz106

29. Osumi, H., Matsusaka, S., Wakatsuki, T., Suenaga, M., Shinozaki, E., Mizunuma, N.: Angiotensin II type-1 receptor blockers enhance the effects of bevacizumab-based chemotherapy in metastatic colorectal cancer patients. Mol Clin Oncol 3(6), 1295-1300 (2015). doi:10.3892/mco.2015.630

30. Morris, Z.S., Saha, S., Magnuson, W.J., Morris, B.A., Borkenhagen, J.F., Ching, A., Hirose, G., McMurry, V., Francis, D.M., Harari, P.M., Chappell, R., Tsuji, S., Ritter, M.A.: Increased tumor response to neoadjuvant therapy among rectal cancer patients taking angiotensin-converting enzyme inhibitors or angiotensin receptor blockers. Cancer 122(16), 2487-2495 (2016). doi:10.1002/cncr.30079

31. Rombouts, A.J., Hugen, N., Verhoeven, R.H., Kuiper, J.G., Poortmans, P.M., de Wilt, J.H., Nagtegaal, I.D.: Is preoperative chemoradiation in rectal cancer patients modulated by ACE inhibitors? results from the dutch cancer registry. Radiother Oncol 138, 86-92 (2019). doi:10.1016/j.radonc.2019.06.010

32. Gumashta, J., Gumashta, R.: Role of the backbenchers of the renin-angiotensin system ace 2 and at2 receptors in covid-19: Lessons from sars. Cureus 12(6), 8411 (2020). doi:10.7759/cureus.8411

33. Dandona, P., Dhindsa, S., Ghanim, H., Chaudhuri, A.: Angiotensin ii and inflammation: the effect of angiotensin-converting enzyme inhibition and angiotensin ii receptor blockade. J Hum Hypertens 21(1), 20-7 (2007). doi:10.1038/sj.jhh.1002101

Figures

Figure 1 Kaplan-Meier plots of overall survival (OS) for the comparison of patient groups (A) ARBs vs. ACEls and (B) ACEls vs. non-RASls.

Figure 2 The Kaplan-Meier plot of disease-free survival (DFS) for the comparison of patient groups ARB vs ACEI.

Figure 3 The forest plots of hazard ratio results from a reduced multivariate Cox regression model for (A) overall survival (OS) and (B) disease-free survival (DFS) prognostic factors; * indicates $\mathrm{p}<0.05, * * \mathrm{p}<0.01, * * * \mathrm{p}<0.001$.

Table 1: Patient characteristics

\begin{tabular}{|c|c|c|c|c|c|c|c|c|}
\hline & & $\begin{array}{c}\text { Total number of patients } \\
n=242\end{array}$ & $\begin{array}{c}\text { ACEI } \\
\mathrm{n}=123\end{array}$ & $\begin{array}{l}\text { ARB } \\
\mathrm{n}=35\end{array}$ & $\mathrm{p}$ & $\begin{array}{c}\text { RASI } \\
\mathrm{n}=158\end{array}$ & $\begin{array}{c}\text { Non-RASI } \\
\mathrm{n}=84\end{array}$ & $\mathrm{p}$ \\
\hline & & 68 & 69 & 67 & & 68 & 67 & \\
\hline \multirow[t]{2}{*}{ Age } & median (IQR) & $(62$ & $(63$ & $(60.5$ & 0.074 & (62 & (61 & 0.460 \\
\hline & & $-73)$ & $-74)$ & $-69.5)$ & & $-74)$ & $-72)$ & \\
\hline \multirow[t]{2}{*}{ Sex } & Females & $\begin{array}{c}109 \\
(45.04 \%)\end{array}$ & $\begin{array}{c}53 \\
(43.09 \%)\end{array}$ & $\begin{array}{c}21 \\
(60.00 \%)\end{array}$ & 0.087 & $\begin{array}{c}74 \\
(46.84 \%)\end{array}$ & $\begin{array}{c}35 \\
(41.67 \%)\end{array}$ & 0.498 \\
\hline & Males & $\begin{array}{c}133 \\
(54.96 \%)\end{array}$ & $\begin{array}{c}70 \\
(56.91 \%)\end{array}$ & $\begin{array}{c}14 \\
(40.00 \%)\end{array}$ & & $\begin{array}{c}84 \\
(53.16 \%)\end{array}$ & $\begin{array}{c}49 \\
(58.33 \%)\end{array}$ & \\
\hline \multirow[t]{2}{*}{ BMI } & median (IQR) & $(24.6$ & $(24.75$ & $(25.75$ & 0.083 & (24.92 & $(24.575$ & 0.420 \\
\hline & & $-30.475)$ & $-29.82)$ & $-30.95)$ & & $-30.575)$ & $-30.4)$ & \\
\hline \multirow[t]{2}{*}{ CAD } & Yes & $\begin{array}{c}52 \\
(21.49 \%)\end{array}$ & $\begin{array}{c}25 \\
(20.33 \%)\end{array}$ & $\begin{array}{c}5 \\
(14.29 \%)\end{array}$ & 0.476 & $\begin{array}{c}30 \\
(18.99 \%)\end{array}$ & $\begin{array}{c}22 \\
(26.19 \%)\end{array}$ & 0.250 \\
\hline & No & $\begin{array}{c}190 \\
(78.51 \%)\end{array}$ & $\begin{array}{c}98 \\
(79.67 \%)\end{array}$ & $\begin{array}{c}30 \\
(85.71 \%)\end{array}$ & & $\begin{array}{c}128 \\
(81.01 \%)\end{array}$ & $\begin{array}{c}62 \\
(73.81 \%)\end{array}$ & \\
\hline DM & Yes & $\begin{array}{c}70 \\
(28.93 \%)\end{array}$ & $\begin{array}{c}35 \\
(28.46 \%)\end{array}$ & $\begin{array}{c}12 \\
(34.29 \%)\end{array}$ & 0.533 & $\begin{array}{c}47 \\
(29.75 \%)\end{array}$ & $\begin{array}{c}23 \\
(27.38 \%)\end{array}$ & 0.767 \\
\hline \multirow[t]{2}{*}{$\mathrm{CCl}$} & $0-2$ & $\begin{array}{c}123 \\
(50.83)\end{array}$ & $\begin{array}{c}61 \\
(49.59 \%)\end{array}$ & $\begin{array}{c}18 \\
(51.43 \%)\end{array}$ & 1 & $\begin{array}{c}79 \\
(50.00 \%)\end{array}$ & $\begin{array}{c}44 \\
(52.38 \%)\end{array}$ & 0.787 \\
\hline & $>2$ & $\begin{array}{c}119 \\
(49.17)\end{array}$ & $\begin{array}{c}62 \\
(50.41 \%)\end{array}$ & $\begin{array}{c}17 \\
(48.57 \%)\end{array}$ & & $\begin{array}{c}79 \\
(50.00 \%)\end{array}$ & $\begin{array}{c}40 \\
(47.62 \%)\end{array}$ & \\
\hline cTNM Stage & 2 & $\begin{array}{c}73 \\
(30.17)\end{array}$ & $\begin{array}{c}37 \\
(30.08 \%)\end{array}$ & $\begin{array}{c}16 \\
(45.71 \%)\end{array}$ & 0.105 & $\begin{array}{c}53 \\
(33.54 \%)\end{array}$ & $\begin{array}{c}20 \\
(23.81 \%)\end{array}$ & 0.141 \\
\hline
\end{tabular}




\begin{tabular}{|c|c|c|c|c|c|c|c|c|}
\hline & 3 & $\begin{array}{c}169 \\
(69.83)\end{array}$ & $\begin{array}{c}86 \\
(69.92 \%)\end{array}$ & $\begin{array}{c}19 \\
(54.29 \%)\end{array}$ & & $\begin{array}{c}105 \\
(66.46 \%)\end{array}$ & $\begin{array}{c}64 \\
(76.19 \%)\end{array}$ & \\
\hline \multirow[t]{3}{*}{ Distance to the anal verge } & $<=5 \mathrm{~cm}$ & $\begin{array}{c}138 \\
(57.02 \%)\end{array}$ & $\begin{array}{c}76 \\
(61.79 \%)\end{array}$ & $\begin{array}{c}17 \\
(48.57 \%)\end{array}$ & 0.350 & $\begin{array}{c}93 \\
(58.86 \%)\end{array}$ & $\begin{array}{c}45 \\
(53.57 \%)\end{array}$ & 0.663 \\
\hline & $6-10 \mathrm{~cm}$ & $\begin{array}{c}69 \\
(28.51 \%)\end{array}$ & $\begin{array}{c}32 \\
(26.02 \%)\end{array}$ & $\begin{array}{c}12 \\
(34.29 \%)\end{array}$ & & $\begin{array}{c}44 \\
(27.85 \%)\end{array}$ & $\begin{array}{c}25 \\
(29.76 \%)\end{array}$ & \\
\hline & $11-15 \mathrm{~cm}$ & $\begin{array}{c}35 \\
(14.46 \%)\end{array}$ & $\begin{array}{c}15 \\
(12.20 \%)\end{array}$ & $\begin{array}{c}6 \\
(17.14 \%)\end{array}$ & & $\begin{array}{c}21 \\
(13.29 \%)\end{array}$ & $\begin{array}{c}14 \\
(16.67 \%)\end{array}$ & \\
\hline \multirow[t]{2}{*}{ Neoadjuvant } & RT & $\begin{array}{c}178 \\
(73.55 \%)\end{array}$ & $\begin{array}{c}93 \\
(75.61 \%)\end{array}$ & $\begin{array}{c}25 \\
(71.43 \%)\end{array}$ & 0.661 & $\begin{array}{c}118 \\
(74.68 \%)\end{array}$ & $\begin{array}{c}60 \\
(71.43 \%)\end{array}$ & 0.647 \\
\hline & CRT & $\begin{array}{c}64 \\
(26.45 \%)\end{array}$ & $\begin{array}{c}30 \\
(24.39 \%)\end{array}$ & $\begin{array}{c}10 \\
(28.57 \%)\end{array}$ & & $\begin{array}{c}40 \\
(25.32 \%)\end{array}$ & $\begin{array}{c}24 \\
(28.57 \%)\end{array}$ & \\
\hline \multirow[t]{3}{*}{ Surgery } & AR & $\begin{array}{c}135 \\
(55.79 \%)\end{array}$ & $\begin{array}{c}67 \\
(54.47 \%)\end{array}$ & $\begin{array}{c}19 \\
(54.29 \%)\end{array}$ & 1 & $\begin{array}{c}86 \\
(54.43 \%)\end{array}$ & $\begin{array}{c}49 \\
(58.33 \%)\end{array}$ & 0.237 \\
\hline & APR & $\begin{array}{c}96 \\
(39.67 \%)\end{array}$ & $\begin{array}{c}52 \\
(42.28 \%)\end{array}$ & $\begin{array}{c}15 \\
(42.86 \%)\end{array}$ & & $\begin{array}{c}67 \\
(42.41 \%)\end{array}$ & $\begin{array}{c}29 \\
(34.52 \%)\end{array}$ & \\
\hline & Hartm & $\begin{array}{c}11 \\
(4.55 \%)\end{array}$ & $\begin{array}{c}4 \\
(3.25 \%)\end{array}$ & $\begin{array}{c}1 \\
(2.86 \%)\end{array}$ & & $\begin{array}{c}5 \\
(3.16 \%)\end{array}$ & $\begin{array}{c}6 \\
(7.14 \%)\end{array}$ & \\
\hline \multirow[t]{2}{*}{ Clavien } & $0-2$ & $\begin{array}{c}204 \\
(84.30 \%)\end{array}$ & $\begin{array}{c}107 \\
(86.99 \%)\end{array}$ & $\begin{array}{c}33 \\
(94.29 \%)\end{array}$ & 0.366 & $\begin{array}{c}140 \\
(88.61 \%)\end{array}$ & $\begin{array}{c}64 \\
(76.19 \%)\end{array}$ & 0.015 \\
\hline & $>2$ & $\begin{array}{c}38 \\
(15.70 \%)\end{array}$ & $\begin{array}{c}16 \\
(13.01 \%)\end{array}$ & $\begin{array}{c}2 \\
(5.71 \%)\end{array}$ & & $\begin{array}{c}18 \\
(11.39 \%)\end{array}$ & $\begin{array}{c}20 \\
(23.81 \%)\end{array}$ & \\
\hline \multirow[t]{3}{*}{ урт } & $0-1$ & $\begin{array}{c}25 \\
(10.33 \%)\end{array}$ & $\begin{array}{c}9 \\
(7.32 \%)\end{array}$ & $\begin{array}{c}4 \\
(11.43 \%)\end{array}$ & 0.454 & $\begin{array}{c}13 \\
(8.23 \%)\end{array}$ & $\begin{array}{c}12 \\
(14.29 \%)\end{array}$ & 0.143 \\
\hline & 2 & $\begin{array}{c}86 \\
(35.54 \%)\end{array}$ & $\begin{array}{c}51 \\
(41.46 \%)\end{array}$ & $\begin{array}{c}11 \\
(31.43 \%)\end{array}$ & & $\begin{array}{c}62 \\
(39.24 \%)\end{array}$ & $\begin{array}{c}24 \\
(28.57 \%)\end{array}$ & \\
\hline & $3-4$ & $\begin{array}{c}131 \\
(54.13 \%)\end{array}$ & $\begin{array}{c}63 \\
(51.22 \%)\end{array}$ & $\begin{array}{c}20 \\
(57.14 \%)\end{array}$ & & $\begin{array}{c}83 \\
(52.53 \%)\end{array}$ & $\begin{array}{c}48 \\
(57.14 \%)\end{array}$ & \\
\hline \multirow[t]{3}{*}{ ypN } & positive & $\begin{array}{c}91 \\
(37.60 \%)\end{array}$ & $\begin{array}{c}43 \\
(34.96 \%)\end{array}$ & $\begin{array}{c}14 \\
(40.00 \%)\end{array}$ & 0.690 & $\begin{array}{c}57 \\
(36.08 \%)\end{array}$ & $\begin{array}{c}34 \\
(40.48 \%)\end{array}$ & 0.577 \\
\hline & negative & $\begin{array}{c}151 \\
(62.40 \%)\end{array}$ & $\begin{array}{c}80 \\
(65.04 \%)\end{array}$ & $\begin{array}{c}21 \\
(60.00 \%)\end{array}$ & & $\begin{array}{c}101 \\
(63.92 \%)\end{array}$ & $\begin{array}{c}50 \\
(59.52 \%)\end{array}$ & \\
\hline & & 11.5 & 12 & 11 & & 11.5 & 11.5 & \\
\hline LNY & median (IQR) & $\begin{array}{c}(8 \\
-16)\end{array}$ & $\begin{array}{c}(8 \\
-16)\end{array}$ & $\begin{array}{c}(7.5 \\
-15.5)\end{array}$ & 0.620 & $\begin{array}{c}(8 \\
-16)\end{array}$ & $\begin{array}{c}(8 \\
-16)\end{array}$ & 0.666 \\
\hline \multirow[t]{2}{*}{ TRG } & $0-1$ & $\begin{array}{c}88 \\
(36.36 \%)\end{array}$ & $\begin{array}{c}40 \\
(32.52 \%)\end{array}$ & $\begin{array}{c}9 \\
(25.71 \%)\end{array}$ & 0.537 & $\begin{array}{c}49 \\
(31.01 \%)\end{array}$ & $\begin{array}{c}39 \\
(46.43 \%)\end{array}$ & 0.024 \\
\hline & $2-3$ & $\begin{array}{c}154 \\
(63.64 \%)\end{array}$ & $\begin{array}{c}83 \\
(67.48 \%)\end{array}$ & $\begin{array}{c}26 \\
(74.29 \%)\end{array}$ & & $\begin{array}{c}109 \\
(68.99 \%)\end{array}$ & $\begin{array}{c}45 \\
(53.57 \%)\end{array}$ & \\
\hline \multirow[t]{2}{*}{ LVI } & Yes & $\begin{array}{c}8 \\
(3.31 \%)\end{array}$ & $\begin{array}{c}6 \\
(2.50 \%)\end{array}$ & $\begin{array}{c}0 \\
(0.00 \%)\end{array}$ & 0.340 & $\begin{array}{c}6 \\
(3.80 \%)\end{array}$ & $\begin{array}{c}2 \\
(2.38 \%)\end{array}$ & 0.717 \\
\hline & No & $\begin{array}{c}234 \\
(96.69 \%)\end{array}$ & $\begin{array}{c}117 \\
(97.50 \%)\end{array}$ & $\begin{array}{c}35 \\
(100 \%)\end{array}$ & & $\begin{array}{c}152 \\
(96.20 \%)\end{array}$ & $\begin{array}{c}82 \\
(97.62 \%)\end{array}$ & \\
\hline \multirow[t]{2}{*}{ PNI } & Yes & $\begin{array}{c}9 \\
(3.72 \%)\end{array}$ & $\begin{array}{c}4 \\
(3.25 \%)\end{array}$ & $\begin{array}{c}1 \\
(2.86 \%)\end{array}$ & 1 & $\begin{array}{c}5 \\
(3.16 \%)\end{array}$ & $\begin{array}{c}4 \\
(4.76 \%)\end{array}$ & 0.503 \\
\hline & No & $\begin{array}{c}233 \\
(96.28 \%)\end{array}$ & $\begin{array}{c}119 \\
(96.75 \%)\end{array}$ & $\begin{array}{c}34 \\
(97.14 \%)\end{array}$ & & $\begin{array}{c}153 \\
(96.84 \%)\end{array}$ & $\begin{array}{c}80 \\
(95.24 \%)\end{array}$ & \\
\hline \multirow[t]{2}{*}{ Adjuvant CT } & Yes & $\begin{array}{c}81 \\
(33.47 \%)\end{array}$ & $\begin{array}{c}41 \\
(33.33 \%)\end{array}$ & $\begin{array}{c}12 \\
(34.29 \%)\end{array}$ & 1 & $\begin{array}{c}53 \\
(33.54 \%)\end{array}$ & $\begin{array}{c}28 \\
(33.33 \%)\end{array}$ & 1 \\
\hline & No & $\begin{array}{c}161 \\
(66.53 \%)\end{array}$ & $\begin{array}{c}82 \\
(66.67 \%)\end{array}$ & $\begin{array}{c}23 \\
(65.71 \%)\end{array}$ & & $\begin{array}{c}105 \\
(66.46 \%)\end{array}$ & $\begin{array}{c}56 \\
(66.67 \%)\end{array}$ & \\
\hline \multirow[t]{2}{*}{ Adj CT >3 cycles } & Yes & $\begin{array}{c}73 \\
(30.17 \%)\end{array}$ & $\begin{array}{c}35 \\
(28.46 \%)\end{array}$ & $\begin{array}{c}13 \\
(37.14 \%)\end{array}$ & 0.405 & $\begin{array}{c}48 \\
(30.38 \%)\end{array}$ & $\begin{array}{c}25 \\
(29.76 \%)\end{array}$ & 1 \\
\hline & No & $\begin{array}{c}169 \\
(69.83 \%)\end{array}$ & $\begin{array}{c}88 \\
(71.54 \%)\end{array}$ & $\begin{array}{c}22 \\
(62.86 \%)\end{array}$ & & $\begin{array}{c}110 \\
(69.62 \%)\end{array}$ & $\begin{array}{c}59 \\
(70.24 \%)\end{array}$ & \\
\hline CT cycles & Median (IQR) & $\begin{array}{c}1 \\
(0 \\
-4.75)\end{array}$ & $\begin{array}{c}1 \\
(0 \\
-4)\end{array}$ & $\begin{array}{c}0 \\
(0 \\
-6)\end{array}$ & 0.711 & $\begin{array}{c}0.5 \\
(0 \\
-4)\end{array}$ & $\begin{array}{c}1 \\
(0 \\
-5.25)\end{array}$ & 0.480 \\
\hline
\end{tabular}

SD- standard deviation, ACEI- angiotensin-converting enzyme inhibitors, ARB- angiotensin receptor blockers, RASI- renin-angiotensin system inhibitors, BMI- body mass index, CAD- coronary artery disease, $\mathrm{AH}$ - arterial hypertension, DM- diabetes mellitus, $\mathrm{CCl}$ Charlson Comorbidity Index, RT- radiotherapy, CRT- chemoradiotherapy, AR- anterior resection, APR- abdominoperineal resection, Hartm- Hartmann's procedure, LNY- lymph node yield, TRG- tumor regression grade, LVI- lymphovascular invasion, PNI- perineural invasion, CT- chemotherapy 


\begin{tabular}{|c|c|c|c|c|c|c|c|}
\hline & & $\begin{array}{c}\text { ACEI } \\
n=123 \\
n(\%)\end{array}$ & $\begin{array}{l}\text { ARB } \\
n=35 \\
n(\%)\end{array}$ & $\mathrm{p}$ & $\begin{array}{c}\text { RASI } \\
n=158 \\
n(\%)\end{array}$ & $\begin{array}{c}\text { Non-RASI } \\
n=84 \\
n(\%)\end{array}$ & $\mathrm{p}$ \\
\hline \multirow[t]{2}{*}{ Alpha blockers } & Yes & $10(8.13 \%)$ & $3(8.57 \%)$ & 1 & $13(8.23 \%)$ & $6(7.14 \%)$ & 1 \\
\hline & No & $113(91.87 \%)$ & $32(91.43 \%)$ & & $145(91.77 \%)$ & $78(92.86 \%)$ & \\
\hline \multirow[t]{2}{*}{ Beta blockers } & Yes & $64(52.03 \%)$ & $13(37.14 \%)$ & 0.130 & $77(48.73 \%)$ & $60(71.43 \%)$ & 0.001 \\
\hline & No & $59(47.97 \%)$ & $22(62.86 \%)$ & & $81(51.27 \%)$ & $24(28.57 \%)$ & \\
\hline \multirow[t]{2}{*}{ Calcium channel blockers } & Yes & $29(23.58 \%)$ & $7(20.00 \%)$ & 0.820 & $36(22.78 \%)$ & $19(22.62 \%)$ & 1 \\
\hline & No & $94(76.42 \%)$ & $28(80.00 \%)$ & & $122(77.22 \%)$ & $65(77.38 \%)$ & \\
\hline \multirow[t]{2}{*}{ Diuretics } & Yes & $35(28.46 \%)$ & $15(42.86 \%)$ & 0.148 & $50(31.65 \%)$ & $31(36.90 \%)$ & 0.475 \\
\hline & No & $88(71.54 \%)$ & $20(57.14 \%)$ & & $108(68.35 \%)$ & $53(63.10 \%)$ & \\
\hline \multirow[t]{2}{*}{ Nitrates } & Yes & $13(10.57 \%)$ & $1(2.86 \%)$ & 0.308 & $14(8.86 \%)$ & $9(10.71 \%)$ & 0.650 \\
\hline & No & $110(89.43 \%)$ & $34(97.14 \%)$ & & $144(91.14 \%)$ & $75(89.29 \%)$ & \\
\hline \multirow[t]{2}{*}{ Statins } & Yes & $6(4.88 \%)$ & $2(5.71 \%)$ & 1 & $8(5.06 \%)$ & $2(2.38 \%)$ & 0.501 \\
\hline & No & $117(95.12 \%)$ & $33(94.29 \%)$ & & $150(94.94 \%)$ & $82(97.62 \%)$ & \\
\hline
\end{tabular}

Table 3: RASIs (ACEls and ARBs) used in the study groups

\begin{tabular}{ccc}
\hline Group & Drug & $\mathrm{n}(\%)$ \\
\hline ACEI & ramipril & $49(39.8)$ \\
& enalapril & $28(22.8)$ \\
& perindopril & $16(13.0)$ \\
& cilazapril & $8(6.5)$ \\
& lisinopril & $8(6.5)$ \\
& ramipril & $5(4.1)$ \\
& quinapril & $4(3.3)$ \\
& trandolapril & $3(2.4)$ \\
& imidapril & $1(0.8)$ \\
& zofenopril & $1(0.8)$ \\
ARB & losartan & $18(51.4)$ \\
& valsartan & $11(31.4)$ \\
& telmisartan & $6(17.2)$ \\
\hline
\end{tabular}

Table 4: Multivariate Cox proportional hazards models for OS and DFS

\begin{tabular}{|c|c|c|c|c|c|c|c|c|c|c|c|c|}
\hline Variables & $\begin{array}{c}\text { OS } \\
\text { uHR } \\
(95 \% \mathrm{Cl})\end{array}$ & $\mathrm{p}$ & $\begin{array}{c}\mathrm{mHR} \\
(95 \% \mathrm{Cl})\end{array}$ & $\mathrm{p}$ & $\begin{array}{c}\text { mrHR } \\
(95 \% \mathrm{Cl})\end{array}$ & $\mathrm{p}$ & $\begin{array}{c}\text { DFS } \\
\text { uHR } \\
(95 \% \mathrm{Cl})\end{array}$ & $\mathrm{p}$ & $\begin{array}{c}\mathrm{mHR} \\
(95 \% \mathrm{Cl})\end{array}$ & $\mathrm{p}$ & $\begin{array}{c}\mathrm{mrHR} \\
(95 \% \mathrm{Cl})\end{array}$ & $\mathrm{p}$ \\
\hline \multicolumn{13}{|l|}{ Age } \\
\hline & $\begin{array}{c}1.045 \\
(1.017 \\
-1.073)\end{array}$ & 0.002 & $\begin{array}{r}1.044 \\
(1.016 \\
-1.074)\end{array}$ & 0.002 & $\begin{array}{c}1.044 \\
(1.016 \\
-1.073)\end{array}$ & 0.002 & $\begin{array}{r}1.010 \\
(0.980 \\
-1.042)\end{array}$ & 0.515 & & & & \\
\hline \multicolumn{13}{|l|}{ Sex } \\
\hline Females & $\begin{array}{c}\text { [Refere } \\
\text { nce] } 1 \\
1.199\end{array}$ & & & & & & $\begin{array}{c}\text { [Refere } \\
\text { nce] } 1 \\
1.326\end{array}$ & & & & & \\
\hline Males & $\begin{array}{r}(0.786 \\
-1.045)\end{array}$ & 0.399 & & & & & $\begin{array}{c}(0.804 \\
-2.186)\end{array}$ & 0.269 & & & & \\
\hline \multicolumn{13}{|l|}{ BMI } \\
\hline & $\begin{array}{r}0.995 \\
(0.950 \\
-1.041)\end{array}$ & 0.816 & & & & & $\begin{array}{r}1.033 \\
(0.983 \\
-1.087)\end{array}$ & 0.201 & & & & \\
\hline \multicolumn{13}{|l|}{ CAD } \\
\hline No & $\begin{array}{c}\text { [Refere } \\
\text { nce] } 1 \\
1.158\end{array}$ & & & & & & $\begin{array}{c}\text { [Refere } \\
\text { nce] } 1 \\
0.819\end{array}$ & & & & & \\
\hline Yes & $\begin{array}{r}(0.710 \\
-1.888)\end{array}$ & 0.557 & & & & & $\begin{array}{c}(0.437 \\
-1.532)\end{array}$ & 0.531 & & & & \\
\hline DM & & & & & & & & & & & & \\
\hline No & $\begin{array}{c}\text { [Refere } \\
\text { nce] } 1 \\
1.135\end{array}$ & & & & & & $\begin{array}{c}\text { [Refere } \\
\text { nce] } 1 \\
0.931\end{array}$ & & & & & \\
\hline Yes & $\begin{array}{r}(0.726 \\
-1.774)\end{array}$ & 0.579 & & & & & $\begin{array}{r}(0.540 \\
-1.603)\end{array}$ & 0.796 & & & & \\
\hline
\end{tabular}




\begin{tabular}{|c|c|c|c|c|c|c|c|c|c|c|c|c|}
\hline \multicolumn{13}{|l|}{$\mathrm{CCl}$} \\
\hline \multirow{3}{*}{$0-2$} & [Refere & & & & & & [Refere & & & & & \\
\hline & nce] 1 & & & & & & nce] 1 & & & & & \\
\hline & 1.260 & & & & & & 0.890 & & & & & \\
\hline \multirow[t]{2}{*}{$>2$} & $(0.832$ & 0.275 & & & & & $(0.547$ & 0.641 & & & & \\
\hline & $-1.906)$ & & & & & & $-1.450)$ & & & & & \\
\hline cTNM & & & & & & & & & & & & \\
\hline & & & & & & & & & & & & \\
\hline \multirow{3}{*}{2} & [Refere & & & & & & [Refere & & & & & \\
\hline & nce] 1 & & & & & & nce] 1 & & & & & \\
\hline & 1.311 & & & & & & 1.245 & & & & & \\
\hline \multirow[t]{2}{*}{3} & $(0.822$ & 0.256 & & & & & $(0.723$ & 0.430 & & & & \\
\hline & $-2.093)$ & & & & & & $-2.143)$ & & & & & \\
\hline \multirow{2}{*}{\multicolumn{13}{|c|}{$\begin{array}{l}\text { Distance to } \\
\text { the anal } \\
\text { verge }\end{array}$}} \\
\hline & & & & & & & & & & & & \\
\hline \multirow{3}{*}{$<=5 \mathrm{~cm}$} & [Refere & & & & & & [Refere & & [Refere & & & \\
\hline & nce] 1 & & & & & & nce] 1 & & nce] 1 & & & \\
\hline & 0.871 & & & & & & 0.810 & & 0.803 & & & \\
\hline $6-10 \mathrm{~cm}$ & $(0.539$ & 0.574 & & & & & $(0.465$ & 0.457 & $(0.456$ & 0.449 & & \\
\hline & $-1.408)$ & & & & & & $-1.411)$ & & $-1.416)$ & & & \\
\hline & 0.949 & & & & & & 0.538 & & 0.605 & & & \\
\hline $11-15 \mathrm{~cm}$ & $(0.495$ & 0.874 & & & & & $(0.228$ & 0.157 & $(0.249$ & 0.265 & & \\
\hline & $-1.818)$ & & & & & & $-1.268)$ & & $-1.465)$ & & & \\
\hline $\begin{array}{l}\text { Neoad } \\
\text { juvant }\end{array}$ & & & & & & & & & & & & \\
\hline$R T$ & [Refere & & [Refere & & & & [Refere & & [Refere & & & \\
\hline RI & nce] 1 & & nce] 1 & & & & nce] 1 & & nce] 1 & & & \\
\hline & 0.573 & & 0.743 & & & & 0.552 & & 0.783 & & & \\
\hline CRT & $(0.333$ & 0.044 & $(0.425$ & 0.298 & & & $(0.295$ & 0.063 & $(0.406$ & 0.467 & & \\
\hline & $-0.985)$ & & $-1.300)$ & & & & $-1.033)$ & & $-1.512)$ & & & \\
\hline Surgery & & & & & & & & & & & & \\
\hline$A P$ & [Refere & & [Refere & & & & [Refere & & & & & \\
\hline $\mathrm{AR}$ & nce] 1 & & nce] 1 & & & & nce] 1 & & & & & \\
\hline & 1.455 & & 1.398 & & & & 1.332 & & & & & \\
\hline APR & $(0.960$ & 0.077 & $(0.912$ & 0.125 & & & $(0.806$ & 0.264 & & & & \\
\hline & $-2.205)$ & & $-2.144)$ & & & & $-2.201)$ & & & & & \\
\hline & 0.635 & & 0.547 & & & & 1.688 & & & & & \\
\hline Hartm & $(0.087$ & 0.654 & $(0.072$ & 0.560 & & & $(0.515$ & 0.387 & & & & \\
\hline & $-4.637)$ & & $-4.153)$ & & & & $-5.527)$ & & & & & \\
\hline Clavien & & & & & & & & & & & & \\
\hline ? & [Refere & & & & & & [Refere & & [Refere & & & \\
\hline $0-2$ & nce] 1 & & & & & & nce] 1 & & nce] 1 & & & \\
\hline & 1.411 & & & & & & 1.645 & & 1.584 & & & \\
\hline$>2$ & $(0.832$ & 0.202 & & & & & $(0.895$ & 0.109 & $(0.782$ & 0.201 & & \\
\hline & $-2.394)$ & & & & & & $-3.022)$ & & $-3.205)$ & & & \\
\hline урТ & & & & & & & & & & & & \\
\hline $0-1$ & [Refere & & [Refere & & [Refere & & [Refere & & [Refere & & [Refere & \\
\hline & nce] 1 & & nce] 1 & & nce] 1 & & nce] 1 & & nce] 1 & & nce] 1 & \\
\hline & 1.943 & & 1.810 & & 1.653 & & 6.396 & & 4.951 & & 5.154 & \\
\hline 2 & $(0.678$ & 0.216 & $(0.617$ & 0.280 & $(0.570$ & 0.355 & $(0.860$ & 0.070 & $(0.657$ & 0.121 & $(0.689$ & 0.110 \\
\hline & $-5.567)$ & & $-5.308)$ & & $-4.793)$ & & $-47.556)$ & & $-37.345)$ & & $-38.551)$ & \\
\hline & 3.490 & & 2.587 & & 2.449 & & 11.507 & & 6.757 & & $6.910^{\prime}$ & \\
\hline $3-4$ & $(1.268$ & 0.016 & $(0.912$ & 0.074 & $(0.868$ & 0.091 & $(1.584$ & 0.016 & $(0.900$ & 0.063 & $(0.933$ & 0.058 \\
\hline & $-9.608)$ & & $-7.342)$ & & $-6.909)$ & & $-83.595)$ & & $-50.741)$ & & $-51.157)$ & \\
\hline ypN & & & & & & & & & & & & \\
\hline negative & [Refere & & [Refere & & [Refere & & [Refere & & [Refere & & [Refere & \\
\hline & nce] 1 & & nce] 1 & & nce] 1 & & nce] 1 & & nce] 1 & & nce] 1 & \\
\hline & 2.192 & & 2.090 & & 2.157 & & 2.890 & & 2.068 & & 2.310 & \\
\hline positive & $(1.448$ & $<0.001$ & $(1.343$ & 0.001 & $(1.395$ & 0.001 & $(1.769$ & $<0.001$ & $(1.086$ & 0.027 & $(1.374$ & 0.002 \\
\hline & $-3.316)$ & & $-3.251)$ & & $-3.334)$ & & $-4.721)$ & & $-3.939)$ & & $-3.883)$ & \\
\hline LNY & & & & & & & & & & & & \\
\hline & 1.013 & & & & & & 1.018 & & & & & \\
\hline & $(0.982$ & 0.426 & & & & & $(0.980$ & 0.362 & & & & \\
\hline & $-1.045)$ & & & & & & $-1.057)$ & & & & & \\
\hline TRG & & & & & & & & & & & & \\
\hline & [Refere & & & & & & [Refere & & [Refere & & & \\
\hline $0-1$ & nce] 1 & & & & & & nce] 1 & & nce] 1 & & & \\
\hline & 1.296 & & & & & & 1.824 & & 1.339 & & & \\
\hline $2-3$ & $(0.832$ & 0.251 & & & & & $(1.059$ & 0.030 & $(0.750$ & 0.324 & & \\
\hline & $-2.017)$ & & & & & & $-3.144)$ & & $-2.391)$ & & & \\
\hline
\end{tabular}




\begin{tabular}{|c|c|c|c|c|c|c|c|c|c|c|c|c|}
\hline \multirow[t]{2}{*}{ No } & $\begin{array}{c}\text { [Refere } \\
\text { nce] } 1\end{array}$ & & $\begin{array}{c}\text { [Refere } \\
\text { nce] } 1\end{array}$ & & & & $\begin{array}{l}\text { [Refere } \\
\text { nce] } 1\end{array}$ & & $\begin{array}{c}\text { [Refere } \\
\text { nce] } 1\end{array}$ & & $\begin{array}{c}\text { [Refere } \\
\text { nce] } 1\end{array}$ & \\
\hline & 3.920 & & 1.038 & & & & 8.975 & & 2.367 & & 2.303 & \\
\hline \multirow[t]{2}{*}{ Yes } & $(1.795$ & 0.001 & $(0.440$ & 0.932 & & & $(3.765$ & $<0.001$ & $(0.771$ & 0.132 & $(0.796$ & 0.124 \\
\hline & $-8.562)$ & & $-2.447)$ & & & & $-21.397)$ & & $-7.258)$ & & $-6.665)$ & \\
\hline \multicolumn{13}{|l|}{ PNI } \\
\hline \multirow[t]{2}{*}{ No } & $\begin{array}{c}\text { [Refere } \\
\text { nce] } 1\end{array}$ & & $\begin{array}{c}\text { [Refere } \\
\text { nce] } 1\end{array}$ & & $\begin{array}{c}\text { [Refere } \\
\text { nce] } 1\end{array}$ & & $\begin{array}{l}\text { [Refere } \\
\text { nce] } 1\end{array}$ & & $\begin{array}{c}\text { [Refere } \\
\text { nce] } 1\end{array}$ & & $\begin{array}{c}\text { [Refere } \\
\text { nce] } 1\end{array}$ & \\
\hline & 4.912 & & 3.415 & & 3.864 & & 7.619 & & 3.134 & & 4.351 & \\
\hline \multirow[t]{2}{*}{ Yes } & $(2.351$ & $<0.001$ & $(1.519$ & 0.003 & $(1.799$ & 0.001 & (3.412 & $<0.001$ & $(1.056$ & 0.040 & $(1.584$ & 0.004 \\
\hline & $-10.260)$ & & $-7.678)$ & & $-8.301)$ & & $-17.013)$ & & $-9.297)$ & & $-11.954)$ & \\
\hline \multirow{2}{*}{\multicolumn{13}{|c|}{$\begin{array}{c}\text { Adj CT } \\
>3 \text { cycles }\end{array}$}} \\
\hline & & & & & & & & & & & & \\
\hline \multirow{3}{*}{ No } & [Refere & & & & & & [Refere & & [Refere & & & \\
\hline & nce] 1 & & & & & & nce] 1 & & nce] 1 & & & \\
\hline & 1.284 & & & & & & 2.167 & & 1.131 & & & \\
\hline \multirow[t]{2}{*}{ Yes } & $(0.836$ & 0.254 & & & & & $(1.330$ & 0.002 & $(0.582$ & 0.716 & & \\
\hline & $-1.972)$ & & & & & & $-3.529)$ & & $-2.200)$ & & & \\
\hline \multicolumn{13}{|l|}{$\mathrm{AH}$} \\
\hline \multirow{3}{*}{ No } & [Refere & & & & & & [Refere & & & & & \\
\hline & nce] 1 & & & & & & nce] 1 & & & & & \\
\hline & 0.892 & & & & & & 1.936 & & & & & \\
\hline \multirow[t]{2}{*}{ Yes } & $(0.362$ & 0.804 & & & & & $(0.473$ & 0.358 & & & & \\
\hline & $-2.200)$ & & & & & & $-7.923)$ & & & & & \\
\hline \multicolumn{13}{|l|}{ RASI } \\
\hline \multirow{3}{*}{ ACEI } & [Refere & & [Refere & & & & [Refere & & [Refere & & [Refere & \\
\hline & nce] 1 & & nce] 1 & & & & nce] 1 & & nce] 1 & & nce] 1 & \\
\hline & 0.556 & & 0.587 & & 0.536 & & 0.808 & & 0.739 & & 0.739 & \\
\hline non-RASI & $(0.348$ & 0.015 & $(0.361$ & 0.033 & $(0.333$ & 0.010 & $(0.479$ & 0.426 & $(0.423$ & 0.288 & $(0.433$ & 0.267 \\
\hline & $-0.891)$ & & $-0.957)$ & & $-0.864)$ & & $-1.364)$ & & $-1.291)$ & & $-1.261)$ & \\
\hline & 0.366 & & 0.347 & & 0.326 & & 0.449 & & 0.353 & & 0.339 & \\
\hline ARB & $(0.167$ & 0.012 & $(0.156$ & 0.010 & $(0.147$ & 0.006 & $(0.189$ & 0.069 & $(0.140$ & 0.028 & $(0.135$ & 0.021 \\
\hline & $-0.801)$ & & $-0.773)$ & & $-0.724)$ & & $-1.065)$ & & $-0.892)$ & & $-0.850)$ & \\
\hline Alpha & & & & & & & & & & & & \\
\hline blockers & & & & & & & & & & & & \\
\hline $\mathrm{No}$ & [Refere & & & & & & [Refere & & & & & \\
\hline No & nce] 1 & & & & & & nce] 1 & & & & & \\
\hline & 0.857 & & & & & & 0.964 & & & & & \\
\hline Yes & $(0.395$ & 0.695 & & & & & $(0.387$ & 0.937 & & & & \\
\hline & $-1.857)$ & & & & & & $-2.401)$ & & & & & \\
\hline Beta & & & & & & & & & & & & \\
\hline blockers & & & & & & & & & & & & \\
\hline & [Refere & & & & & & [Refere & & & & & \\
\hline No & nce] 1 & & & & & & nce] 1 & & & & & \\
\hline & 0.991 & & & & & & 0.901 & & & & & \\
\hline Yes & $(0.654$ & 0.968 & & & & & $(0.553$ & 0.675 & & & & \\
\hline & $-1.502)$ & & & & & & $-1.468)$ & & & & & \\
\hline Calcium & & & & & & & & & & & & \\
\hline channel & & & & & & & & & & & & \\
\hline blockers & & & & & & & & & & & & \\
\hline $\mathrm{Ne}$ & [Refere & & & & & & [Refere & & & & & \\
\hline & nce] 1 & & & & & & nce] 1 & & & & & \\
\hline & 1.124 & & & & & & 1.084 & & & & & \\
\hline Yes & $(0.699$ & 0.630 & & & & & $(0.617$ & 0.779 & & & & \\
\hline & $-1.805)$ & & & & & & $-1.906)$ & & & & & \\
\hline Diuretics & & & & & & & & & & & & \\
\hline & [Refere & & & & & & [Refere & & & & & \\
\hline No & nce] 1 & & & & & & nce] 1 & & & & & \\
\hline & 0.883 & & & & & & 1.192 & & & & & \\
\hline Yes & $(0.565$ & 0.586 & & & & & $(0.720$ & 0.494 & & & & \\
\hline & $-1.380)$ & & & & & & $-1.973)$ & & & & & \\
\hline
\end{tabular}

OS-overall survival, DFS- disease-free survival, ACEI- angiotensin-converting enzyme inhibitors, ARB- angiotensin receptor blockers, PNIperineural invasion, uHR- univariate hazard ratio, $\mathrm{mHR}$ - hazard ratio for the multivariate model with covariate preselection based on the univariate analysis, mrHR- hazard ratio for the reduced multivariate model with covariate preselection based on the univariate analysis. 
Additional Files

Additional file 1 - Diagram showing the formation of the study group

Additional file 2 - Cox proportional-hazards model

Additional file 3 - Kaplan-Meier Survival Analysis

Additional file 4 - Dataset 
Figures
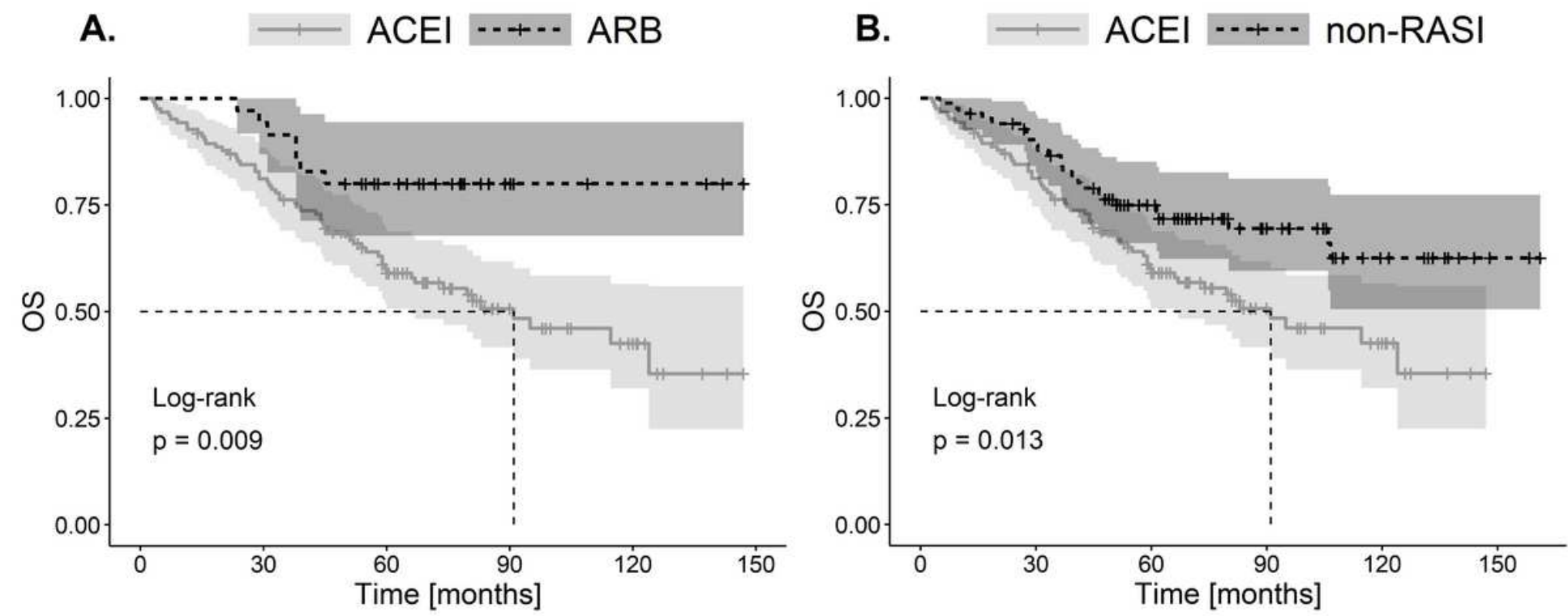

\section{Figure 1}

Kaplan-Meier plots of overall survival (OS) for the comparison of patient groups (A) ARBs vs. ACEls and (B) ACEls vs. non-RASIs. 


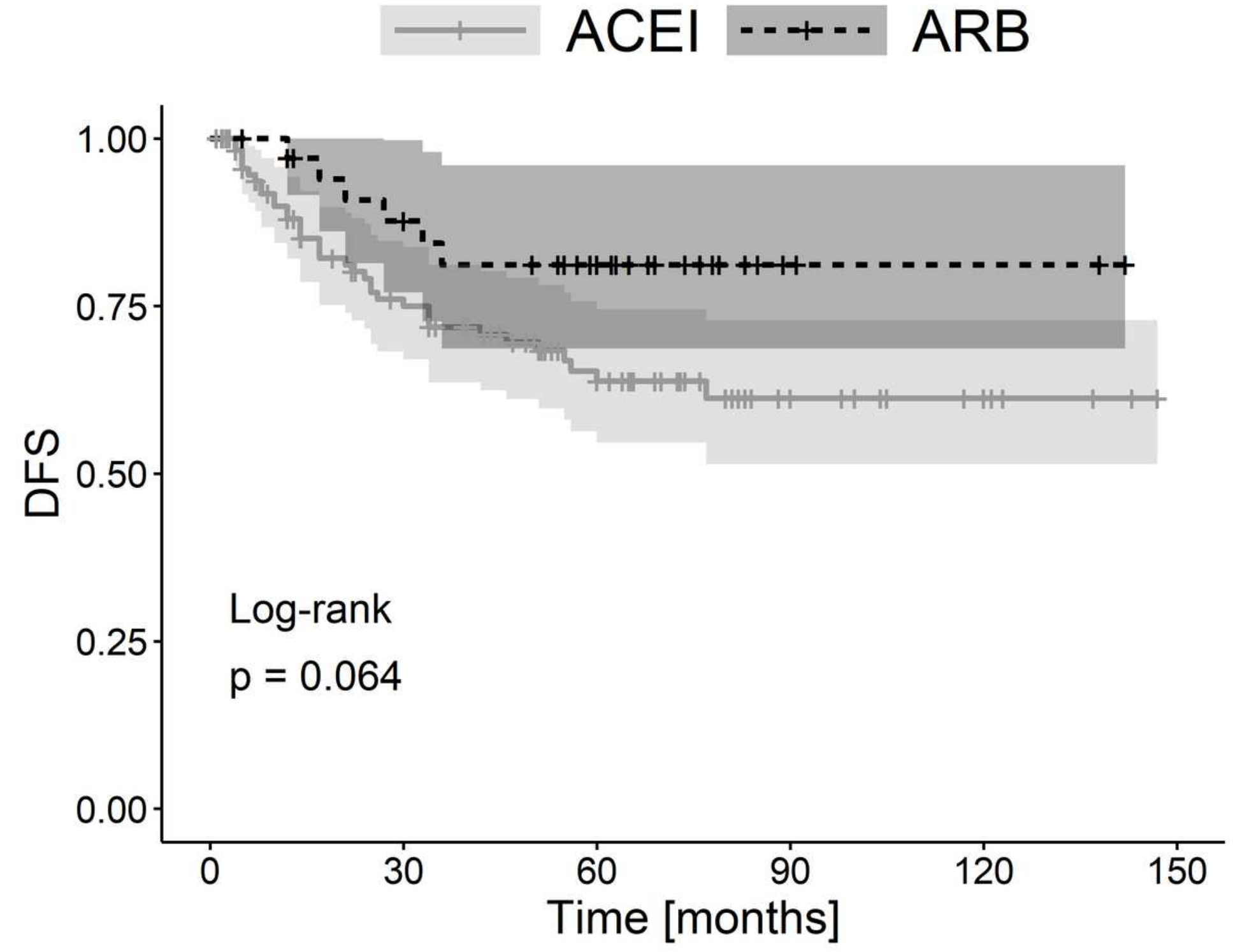

Figure 2

The Kaplan-Meier plot of disease-free survival (DFS) for the comparison of patient groups ARB vs ACEI. 


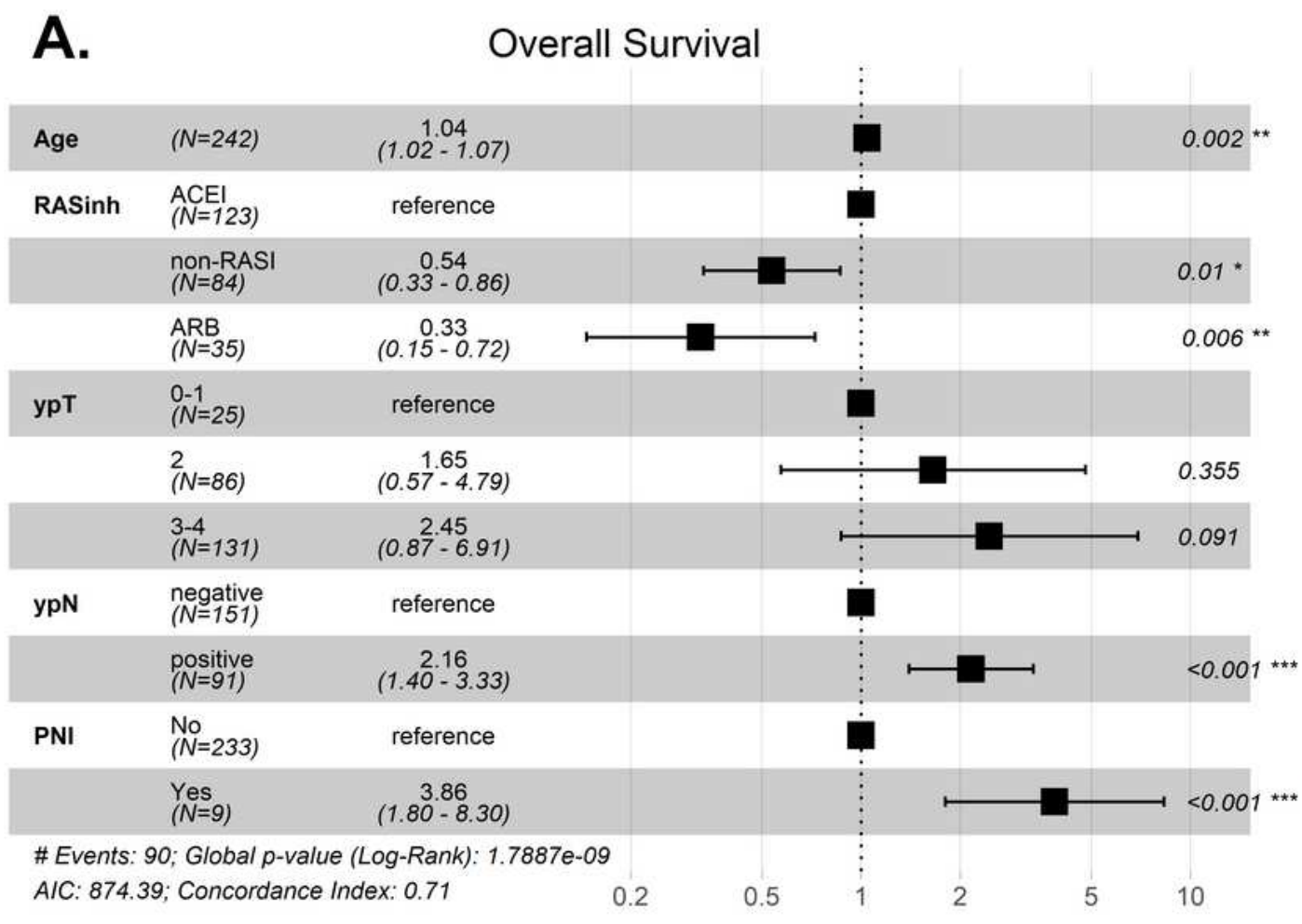

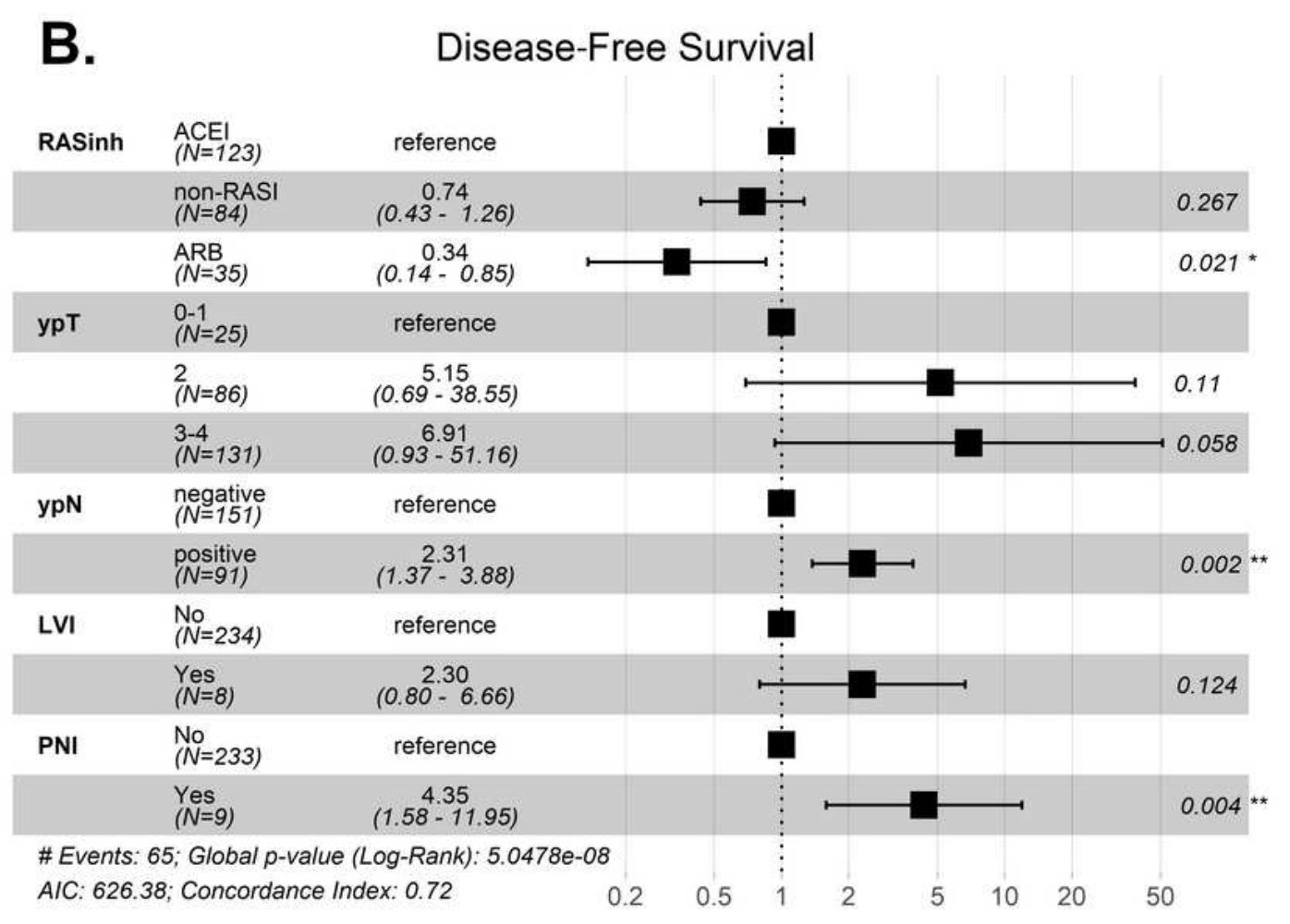

\section{Figure 3}

The forest plots of hazard ratio results from a reduced multivariate Cox regression model for $(A)$ overall survival (OS) and (B) disease-free survival (DFS) prognostic factors; *indicates $p<0.05, * \star p<0.01$, $* \star \star p$ $<0.001$.

\section{Supplementary Files}


This is a list of supplementary files associated with this preprint. Click to download.

- Additionalfile1Diagramshowingtheformationofthestudygroup.docx

- Additionalfile2Coxproportionalhazardsmodel.xIsx

- Additionalfile3KaplanMeierSurvivalAnalysis.docx

- Additionalfile4Dataset.xlsx 